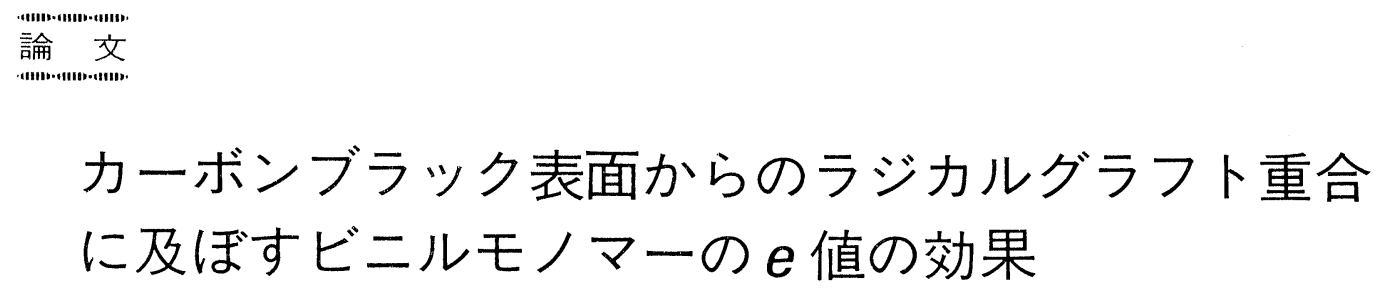

藤木一浩·坪川紀夫* ${ }^{*}$ 曾根康夫*

(平成元年 7 月 13 日受理)

\title{
Effect of $e$-Value of Vinyl Monomers on the Radical Graft Polymerization from Carbon Black Surface
}

\author{
Kazuhiro Fujiki, Norio Tsubokawa*, and Yasuo Sone* \\ Graduate School of Science and Technology, Niigata University \\ *Faculty of Engineering, Niigata University, Ikarashi 2-nocho, \\ Niigata 950-21, Japan
}

The effect of $e$-value of vinyl monomers on the radical graft polymerization initiated by azo or peroxyester groups introduced onto carbon black surface was investigated. In the presence of carbon black having azo-groups (CB-Azo), the polymerization of vinyl monomers with positive $e$-value, such as methyl methacrylate, was initiated to give polymer-grafted carbon black. Although the polymerization of vinyl monomers with negative $e$-value, such as styrene, initiated by $\mathrm{CB}$-Azo was retarded, the corresponding polymer was also grafted onto the surface. On the other hand, carbon black having peroxyester groups (CB-POE) was capable of initiating the polymerization of vinyl monomers with positive $e$-value, but incapable of that with negative $e$-value. Therefore, vinyl polymers with negative $e$-value were unable to graft onto carbon black by use of CB-POE. A similar tendency was observed in the polymerization initiated by 4,4 '-azobis (4-cyanopentanoic acid) or $t$-butyl peroxybenzoate, as a model compound of initiating groups on the carbon black surface, in the presence of untreated carbon black: the polymerization of styrene initiated by $t$-butyl peroxybenzoate was remarkably retarded by carbon black. These results indicate that the radical graft polymerization initiated by initiating groups introduced onto carbon black surface is affected by $e$-value of vinyl monomers.

KEYWORDS: Grafting from carbon black, Vinyl monomer, e-Value, Azo group, Peroxyester group

\section{1. 緒言 \\ カーボンブラック（CB）は,ゴム等の補強充てん剤 や黒色顔料として古くから利用されてきている。また最}

新潟大学大学院自然科学研究科

* 新潟大学工学部応用化学科 : T950-21 新潟市五十嵐 2 の町 8050
近では, 導電性や耐熱性が注目され, 新しい機能素材の 一つとして見直されており，すでに，ポリマー中へ CB を分散させた導電性複合材料が, 面状発熱体や静電気防 止材料として実用化されている。しかしながら, CB を ポリマー中へ均一に分散させることは容易ではなく, し かもポリマー中の CB の分散状態が, 材料の強度や電気 的性質に大きな影響を及ぼすことが知られている。また, 
$\mathrm{CB}$ を多量に配合すると, 樹脂の硬化不良が生じたり材 料の強度が低下するので, てのような問題を解決するた めには, CB 表面の改質が不可欠である。

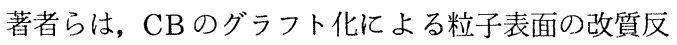
応について, いろいろな角度から検討を重ねてきだ紧。 たとえば, $\mathrm{CB}$ 表面に存在するカルボキシル基やフェノ 一ル性の水酸基などの官能基を利用して, $\mathrm{CB}$ 表面へア ニオン, あるいはカチオン重合開始点を導入し, 粒子表 面からポリマーを生長させると, 効率よく CB 表面へポ リマーがグラフトするととを見出している ${ }^{3)-6) 。 ~}$

一方, ラジカル重合系によるグラフト反応は, 従来, $\mathrm{CB}$ の存在下で過酸化ベンゾイルや 2,2 '-アゾビスイソブ チロニトリルなどの開始剤を用いて, ビニルモノマーの 重合を行い, 生成する生長ポリマーラジカルを CB 表面 に捕えさせる方法で行われてきたが, ての方法では, 非 グラフトポリマーの生成が優勢となるため, グラフト率 の大きなむのを得るととは困難であった 7)-9)。

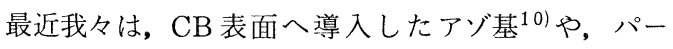
オキシェステル基 ${ }^{11}$ により, ビニルモノマーのラジカル グラフト重合が開始されることを見出した(式(1)，式(2)）。

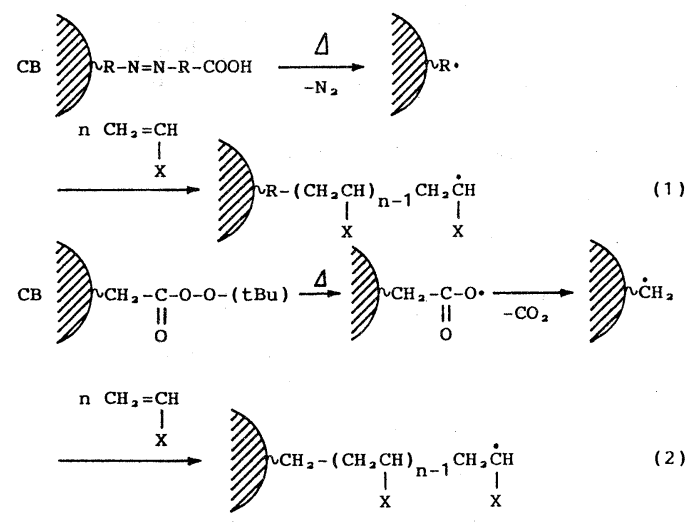

ところで, ビニルモノマーの反応性を決定する因子の 一つしし, Alfreyと Priceによって提起された「e 值」という概念 ${ }^{12)},{ }^{13)}$ がある。乙れは, モノマーのビニ ル基の分極の効果, すなわち, 二重結合の電子密度が重 合反応に及ぼす影響を表した尺度であり，ビニルモノマ 一の置換基が, 電子吸引性の場合は $e$ 值は正となり, 置 換基が電子供与性の場合は, $e$ 值は負となることが知ら れている。

$\mathrm{CB}$ 存在下に拈けるラジカル重合に挄いては, 用いる 開始剤の種類ばかりでなく，モノマーの $e$ 值によっても, 重合性が大きな影響を受けるととが見出されている 9)。従って, グラフト化による CB 界面の精密制御にあ たって, CB表面からのグラフト重合に及ぼすビニルモ
ノマーの $e$ 值の効果の究明は, 不可欠の問題である。

そてで，本研究では，CB 表面にラジカル重合開始基 としてアゾ基およびパーオキシエステル基を導入し, $\mathrm{CB}$ 表面からポリマーを生長させるグラフト重合系において， ビニルモノマーの $e$ 值が重合性によ゙のような影響を及ぼ すかを，CBの存在下でラジカル開始剤を用いる重合系 と, 比較検討することにした。

\section{2. 実験}

\section{$2.1 \mathrm{CB}$ と試薬}

実験に用いた CB は, チャンネル系のNeospectra II (Columbian Carbon Co. 製) であり，その粒子径は

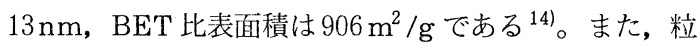
子表面のフェノール性水酸基, カルボキシル基の量は, それぞれ $0.24 \mathrm{meq} / \mathrm{g}$ および $0.40 \mathrm{meq} / \mathrm{g}$ であった。CB は, 使用前に $110^{\circ} \mathrm{C}$ で十分真空乾燥させた。

トリレンジイソシアナート (TDI) は, 和光純薬工業 (株)の一級品を窒素雾囲気下で減圧蒸留して精製し, 使 用㨁前に再度蒸留した。

4, 4'-アゾビス (4-シアノバレリン酸) (ACV) は, 大 塚化学(株)製を，また， $t$-ブチルハイドロパーオキシド $(t-\mathrm{BuOOH})$ と $t$-ブチルパーオキシベンゾエート(BPOB) は, 日本油脂(株)製をそのまま用いた。

ジオキサンは, 金属ナトリウム上で還流した後, 蒸留 して使用した。また, ジメチルスルホキシド(DMSO) は, 水素化カルシウムで脱水した後, 減圧蒸留した。 スチレンは, 関東化学(株)の一級品を常法により精製 し, 酸化バリウムで脱水した後, 減圧蒸留した。メ夕ク リル酸メチル (MMA) は, 和光純薬工業(株)の特級品を 常法により洗浄した後, 無水硫酸ナトリウムで脱水し, 減圧蒸留を繰り返して精製した。アクリロニトリルは, 一級品を常法により精製した後, 常圧蒸留した。N-ビニ ル-2-ピロリドン, メタクリル酸グリシジルは, 関東化 学(株)の一級品を, 4-ビニルピリジン, アクリル酸は, 和光純薬工業(株)の一級品を, メタクリル酸 2-ヒドロキ シエチルは, 東京化成工業(株)の一級品を, それぞれヒ ドロキノン存在下で減圧蒸留した。酢酸ビニル, メチル ビニルケトンは, 関東化学(株)の一級品を常圧蒸留して 使用した。

\section{$2.2 \mathrm{CB}$ 表面へのアゾ基の導入 ${ }^{10)}$}

$200 \mathrm{~m} l$ のナス型フラスコに, 十分真空乾燥させた CB を $5.0 \mathrm{~g}$, TDI $1.0 \mathrm{~m} l$, DMSO $100 \mathrm{~m} l$, 及び少量の $\alpha$ 一ピ コリンを加え ${ }^{15)}$, 16), 窒素雾囲気下, マグネチックスタ ーラでかきまぜながら, $60^{\circ} \mathrm{C}$ で 4 時間反応させた。反 応後, 容器を水冷してから, ACVを $4.0 \mathrm{~g}$ 加え, 引き続 き $25^{\circ} \mathrm{C}$ で 8 時間反応させた。反応後, 遠心分離により 
$\mathrm{CB}$ を沈降させてから，メタノールを加えて十分洗浄し， 末反沁の ACV や溶媒などを除去した。得られたCBは， 室温で真空乾燥させた後，冷暗所保存した。 $\mathrm{CB}$ 表面 に導入されたアゾ基の量は，元素分析によって求めた。

\section{$2.3 \mathrm{CB}$ 表面へのパーオキシエステル基の導入 ${ }^{11)}$}

$200 \mathrm{~m} l$ のナス型フラスコに，十分真空乾燥させた $\mathrm{CB}$ を $5.0 \mathrm{~g}$, アジピン酸ジクロリド $2.5 \mathrm{~m} l$, ジオキサン $100 \mathrm{~m} l$, 㧍よびピリジン $1.2 \mathrm{~m} l$ を加え, 窒素雲閁気下, マグネチ ックスターラでかきまぜながら， $50^{\circ} \mathrm{C} て ゙ 12$ 時間反応さ せた。反応後, 容器を水冷してから, $t-\mathrm{BuOOH}$ を $6 \mathrm{~m} l$ 加え, 引き続き $20^{\circ} \mathrm{C}$ で12 時間反応させた。反応後, 遠 心分離により $\mathrm{CB}$ を沈降させてから, メ夕ノールを加え て十分洗浄し, 未反応の $t$ - $\mathrm{BuOOH}$ や溶媒などを除去し た。得られた CB は, 室温で真空乾燥させた後, 冷暗所 に保存した。CB 表面に導入されたパーオキシエステル 基の量は, ヨウ素滴定法によって求めた ${ }^{17)}$ 。

\section{4 重合方法}

重合管に, CBを $0.3 \mathrm{~g}$, モノマーを $10 \mathrm{~m} l$ 仕込み(未処 理の CB 存在下で，開始剤を用いる重合の場合は，乙れ に所定量の ACV あるいは BPOB を加え), 高真空下で 封管とした。重合は, $70^{\circ} \mathrm{C}$ の恒温水槽中に設けた回転 支持棒に封管を固定し，重合管の上下を，毎分60回の速 さで交替させながら行った。反応後, 生成物を多量の沈 殿剤中に注いで, $\mathrm{CB}$ を含むポリマーを沈殿させた。沈 殿物をろ別し， $40^{\circ} \mathrm{C}$ で恒量になるまで真空乾燥させて から秤量し, 次式に従って重合率を算出した。

$$
\text { 重合率 }(\%)=\frac{\text { 重合生成物 }(\mathrm{g})-\text { 仕込み } \mathrm{CB}(\mathrm{g})}{\text { 仕込みモ/マー }(\mathrm{g})} \times 100
$$

\section{5 グラフト率およびグラフト効率}

生成物を, ポリマ一の良溶媒中へ分散させて, $10^{4} \mathrm{rpm}$ で遠心分離を行い, $\mathrm{CB}$ を完全に沈降させた。ついで, 沈降した CB を筒万紙へ移し,ソックスレー抽出を行 い, 残存する非グラフトポリマーを完全に除去した。グ ラフト率执よびグラフト効率は, 次式により算出した。

$$
\begin{aligned}
& \text { グラフト率 }(\%)= \\
& \begin{aligned}
\text { グラフト効率(\%) } & \frac{\text { グラフト化したモノマー }(\mathrm{g})}{\mathrm{CB}(\mathrm{g})} \times 100 \\
& =\frac{\text { グラフト化したモノマー }(\mathrm{g})}{\text { 生成した全ポリマー }(\mathrm{g})} \times 100
\end{aligned}
\end{aligned}
$$

\section{3. 結果と考察}

\section{$3.1 \mathrm{CB}$ 表面への重合開始基の導入量}

$\mathrm{CB}$ 表面へのアゾ基あるいはパーオキシエステル基の 導入は，式(3)および式(4)の方法により行った ${ }^{10) ， 11 。 ~}$ 元素分析によって求めたアゾ基の導入量, およびョウ

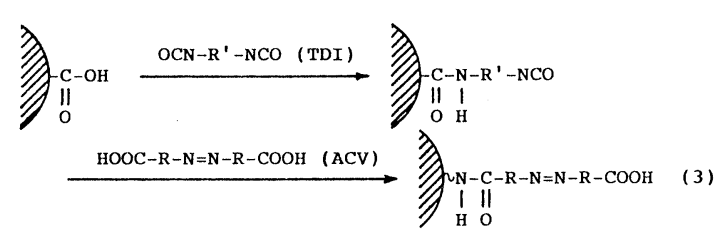

CB-Azo

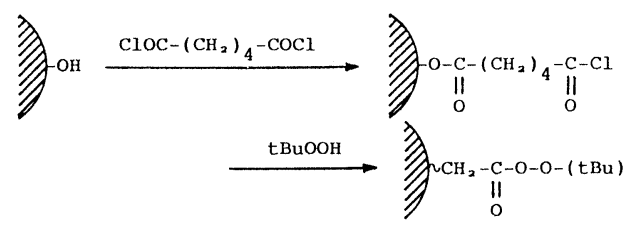

$\mathrm{CB}-\mathrm{POE}$

素滴定によって求めたパーオキシエステル基の導入量を, Table 1 亿示した。このような CB 表面上の重合開始基 により,ビニルモノマーのラジカルグラフト重合が開始 される（式(1)，式(2)。

Table 1 The amount of azo or t-butyl peroxyester groups introduced onto carbon black surface.

\begin{tabular}{lcc}
\hline Carbon black & $\begin{array}{c}\text { Initiating groups } \\
\text { introduced } \\
\text { (meq/g) }\end{array}$ \\
\hline $\mathrm{CB} \sim \mathrm{NHCO}-\mathrm{R}-\mathrm{N}=\mathrm{N}-\mathrm{R}-\mathrm{COOH}$ (CB-Azo) & 0.30 \\
$\mathrm{CB} \sim \mathrm{CH}_{2} \mathrm{CO}-\mathrm{O}-\mathrm{O}-(\mathrm{tBu})$ & (CB-POE) & 0.04 \\
\hline
\end{tabular}

\section{2 アゾ基を導入した CBを用いた場合}

Fig. 1 K，アゾ基を導入した $\mathrm{CB}(\mathrm{CB}-\mathrm{Azo})$ を用いて, $e$ 值が正の MMA の重合を行ったときの, 時間と重合率, 打よびグラフト率との関係を示した。乙れからわかるよ うに, 未処理の CB の存在下では重合は全く進行しない。

これは, CBが重合禁止剂として作用するためである ${ }^{18)-~}$ 21)。乙机に対して, CB-Azo の存在下では MMAの重合 が開始され，グラフト率は約40\%に達するてとがわかっ た。また,グラフト効率は約30\%であった。

さらに, 未処理の $\mathrm{CB}$ を $\mathrm{ACV}$ で処理した後, メタノ ールで十分洗浄した CB には, 重合の開始能力は認めら れなかった。従って, CBに吸着されて残存している $\mathrm{ACV}$ による重合は，無視できるあのと考えられる。乙 のととから，乙の系での MMA の重合は，CB 表面導 入されたアゾ基によって開始されていることが明らかで ある。

Fig. 2 には, 未処理の CB 存在下で, 開始剤として ACV（Fig. 1 で示した CB-Azo表面に存在するアゾ基 と等量) を用いて, MMAの重合を行った結果を示した。 


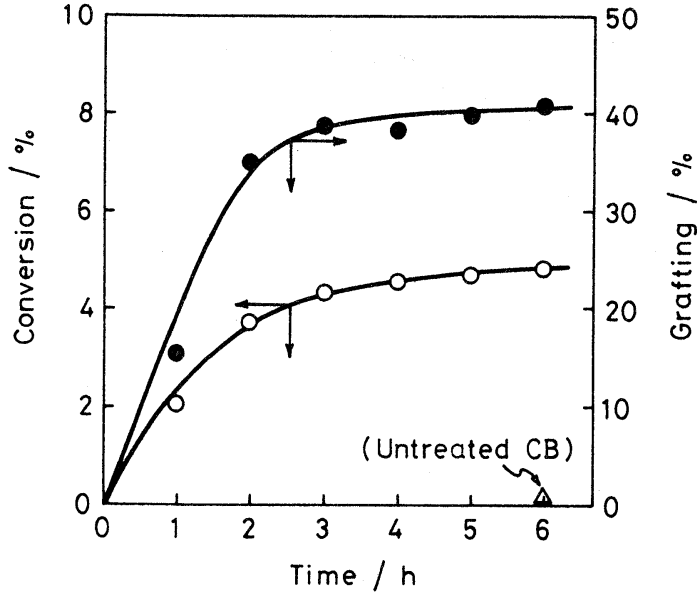

Fig. 1 Polymerization of MMA initiated by CB-Azo. CB-Azo, 0.30 g; MMA, 10.0 $\mathrm{ml} ; 70^{\circ} \mathrm{C}$.

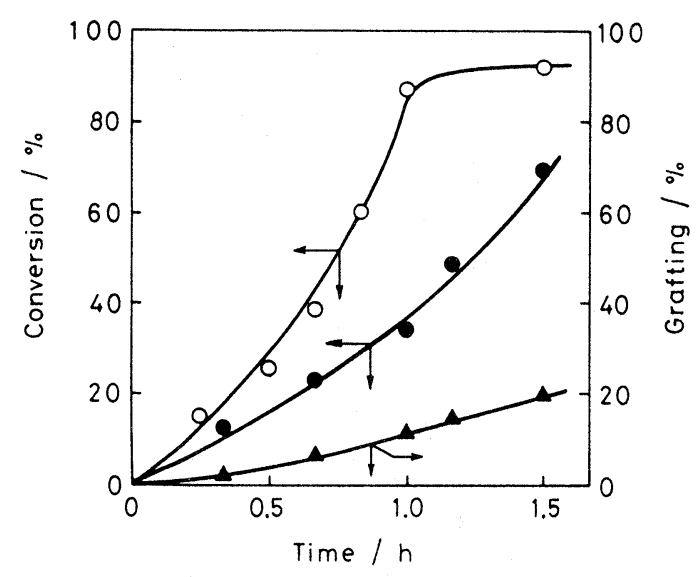

Fig. 2 Polymerization of MMA initiated by $\mathrm{ACV}$ in the presence of untreated $\mathrm{CB}$. CB, $0.30 \mathrm{~g}$; ACV, 0.09 mmol; MMA, $10.0 \mathrm{ml} ; 70^{\circ} \mathrm{C}$.

$\mathrm{O}$ : in the absence of $\mathrm{CB}$.

$\bullet, \triangle$ : in the presence of $\mathrm{CB}$.

これから， $\mathrm{ACV}$ を開始剤に用いると， $\mathrm{CB}$ は重合遅延 剤として作用するてとがわかる。乙のような結果は, $\mathrm{CB}$ の存在下で， 2,2'-アゾビスイソブチロニトリルを開始 剂用いて，ビニルモノマーの重合を行った之きの結果 7)-9) と類似している。乙れは, ACV の作用で CB 表面 に生成する遊離ラジカルに対して, 生長ポリマーラジカ ルと開始剂ラジカルとの競争反応が起とり, その結果, $\mathrm{CB}$ は重合遅延剂として作用するためと推察できる。な お，Fig. 2 の系で得られた $\mathrm{CB} へ$ へポリ MMA のグラフ
ト率は約20\%であり，グラフト効率は約 $1 \%$ であった。 このような結果は, 生成するポリマーの一部は CB 表面 にグラフトするが，大部分は，非グラフトポリマーとな るととを示唆している。従って, Fig.1亿示したように, $\mathrm{CB}$ 表面に導入したアゾ基によって開始される重合系の 方が, 効率よく CB 表面へポリ MMA がグラフトでき るととが明らかである。

Fig. 3 亿は, CB-Azoを用いて, $e$ 值が負のスチレン の重合を行ったときの結果を示した。乙の系であ, 未処 理の CB 存在下では, $\mathrm{CB}$ の重合禁止作用により, 重合

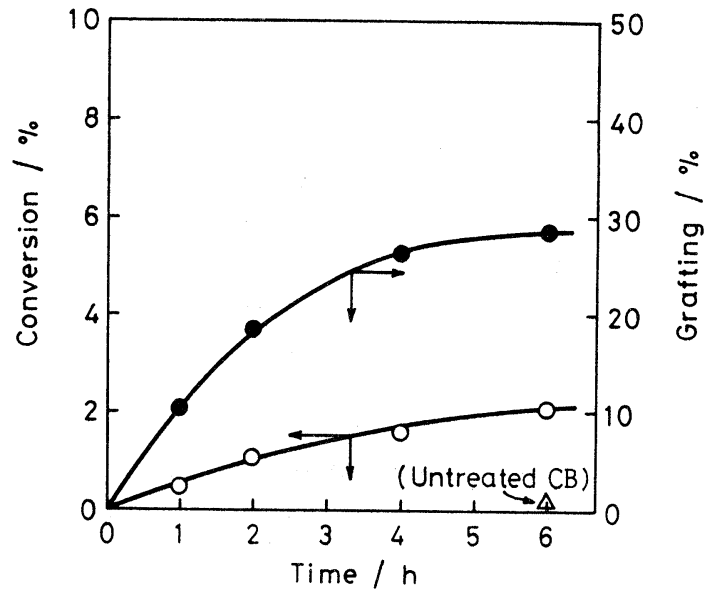

Fig. 3 Polymerization of styrene initiated by CB-Azo. CB-Azo, $0.30 \mathrm{~g}$; styrene, 10.0 $\mathrm{ml} ; 70^{\circ} \mathrm{C}$.

は全く進行しないのに対して, CB-Azo の存在下では 重合が開始されることがわかる。重合率は約 $2 \%$ 程度で あるが，CBへのポリスチレンのグラフト率は，約 $30 \%$ に達した。また,グラフト効率は約45\%であった。

Fig. 4 亿は, 未処理の CB の存在下で, ACV (Fig. 3 の CB-Azoのアゾ基と等量)を開始剤に用いて, スチレ ンの重合を行ったときの結果を示した。乙の系であ, $\mathrm{CB}$ の存在下では重合が遅延され, ポリスチレンのグラフト 率，拉よびグラフト効率は，それぞれ10\%打よび $4 \%$ で あり, Fig. 3 の系と比べて, 非グラフトポリマーの生成 が優勢であるととを物語っている。

Fig. 1 と Fig. 3 とを比較すると, CB による重合の遅 延の効果は, $e$ 值が正の MMA の系よりも, $e$ 值が負の スチレンの系でより大きいてとがわかる。乙のような現 象は, ACV を開始剤に用いたFig. 2 と Fig. 4 の系で あ認められ， CB は，e值が負のモノマーの系で, より 強力な重合遅延剤として作用するてとがわかった。

Table 2 には, CB-Azo を用いて, $e$ 値の異なる種々 


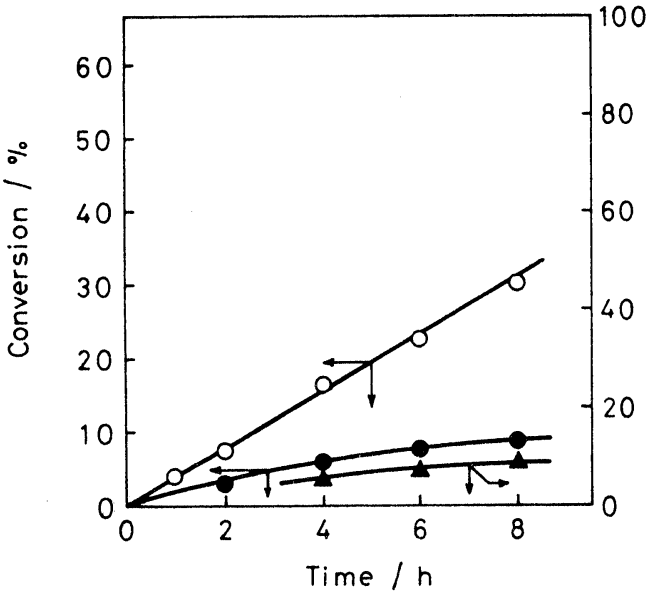

Fig. 4 Polymerization of styrene initiated by $\mathrm{ACV}$ in the presence of untreated $\mathrm{CB}$. $\mathrm{CB}, 0.30 \mathrm{~g} ; \mathrm{ACV}, 0.09 \mathrm{mmol}$; styrene, $10.0 \mathrm{ml} ; 70^{\circ} \mathrm{C}$.

$\mathrm{O}$ : in the absence of $\mathrm{CB}$.

$\bullet, \triangle$ : in the presence of $\mathrm{CB}$.

Table 2 Polymerization of various vinyl monomers initiated by CB-Azo.

\begin{tabular}{lrrr}
\hline Monomer & $e$-value & $\begin{array}{c}\text { Conversion } \\
(\%)\end{array}$ & $\begin{array}{c}\text { Grafting } \\
(\%)\end{array}$ \\
\hline$N$-Vinyl-2-pyrrolidone & -1.14 & 2.6 & 74.3 \\
Styrene & -0.80 & 2.0 & 28.5 \\
4-Vinylpyridine & -0.28 & 10.3 & 79.9 \\
Vinyl acetate & -0.22 & 2.3 & 20.5 \\
2-Hydroxyethyl methacrylate & 0.20 & 1.7 & 24.0 \\
Methyl methacrylate & 0.40 & 4.7 & 40.0 \\
Glycidyl methacrylate & 0.57 & 10.6 & 87.5 \\
Methyl vinyl ketone & 0.68 & 4.6 & 35.2 \\
Acrylic acid & 0.77 & 6.2 & 64.8 \\
Acrylonitrile & 1.20 & 13.1 & 76.2 \\
\hline
\end{tabular}

CB-Azo, $0.30 \mathrm{~g}$; monomer, $10.0 \mathrm{ml} ; 70^{\circ} \mathrm{C}$.

のビニルモノマーの重合を行った結果を示した。重合の 進行には差が認められるが, $e$ 值の正負にかかわりなく, すべてのモノマーの重合が開始され，CB 表面にそれぞ れのポリマーがグラフトすることがわかる。

\section{3 パーオキシェステル基を導入した $\mathrm{CB}$ を用い}

\section{た重合}

Fig. 5 に, パーオキシエステル基を導入したCB $(\mathrm{CB}$ POE) を用いて, MMAの重合を行ったときの結果を示 した。てれから, CB-POEにより MMAの重合が開始 され，CB 表面へのポリ MMAのグラフト率は $45 \%$ 亿達 することがわかる。また, グラフト効率は約40\%であり, $\mathrm{CB}$ 表面へ効率よくポリ MMAがグラフトしているてと を示している。な报，てのような系でも，未処理の $\mathrm{CB}$

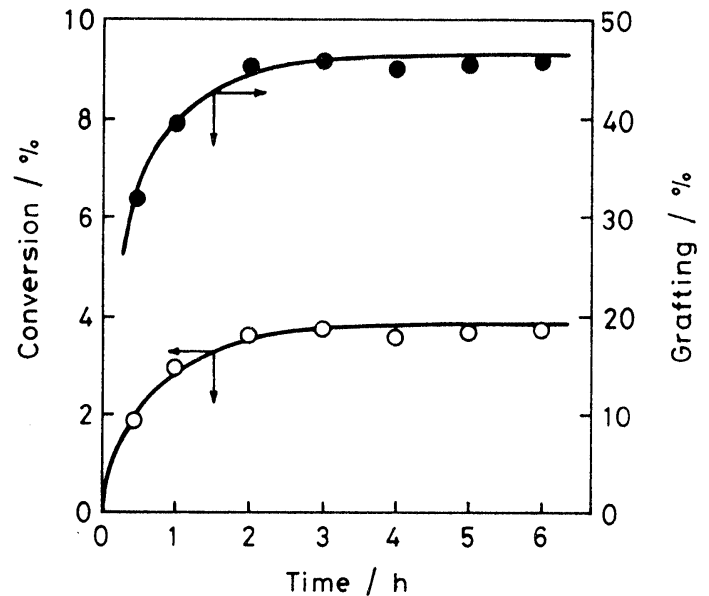

Fig. 5 Polymerization of MMA initiated by CB-POE. CB-POE, 0.30 g; MMA, 10.0 $\mathrm{ml} ; 70^{\circ} \mathrm{C}$.

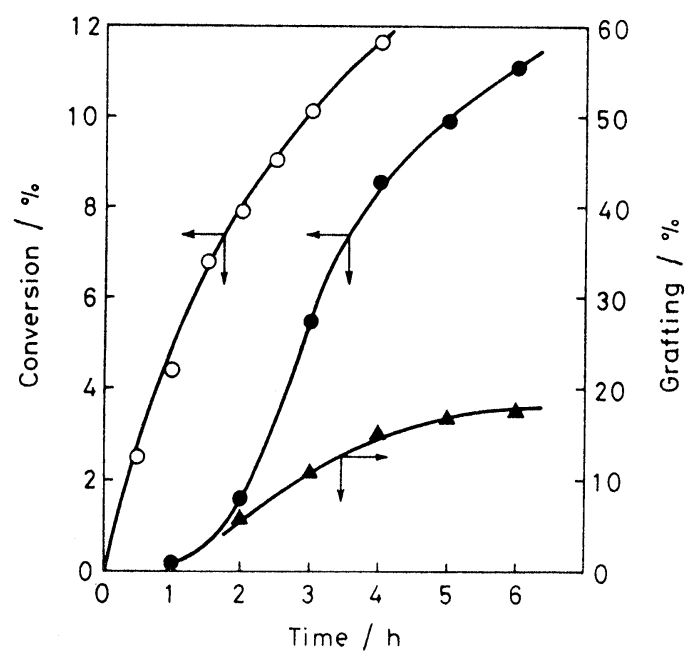

Fig. 6 Polymerization of MMA initiated by $\mathrm{BPOB}$ in the presence of untreated $\mathrm{CB}$. $\mathrm{CB}, 0.30 \mathrm{~g}$; $\mathrm{BPOB}, 0.012 \mathrm{mmol}$; MMA, $10.0 \mathrm{ml} ; 70^{\circ} \mathrm{C}$.

$\mathrm{O}$ : in the absence of $\mathrm{CB}$.

$\bullet, \triangle$ : in the presence of $\mathrm{CB}$.

に $t$ - BuOOH を吸着させただけの $\mathrm{CB} に は$, 重合の開始 能力が認められなかったので, CB 表面に導入したパー オキシエステル基が, 重合開始活性点となっているとと が明らかである。

Fig. 6 亿は, CB 表面上のパーオキシエステル基のモ デルとして, 開始剤に BPOBを, パーオキシエステル基 の導入量と等量用いて, 未処理の $\mathrm{CB}$ 存在下で MMAの 
重合を行ったときの結果を示した。CB の存在下では, 若干の誘導期の後, $\mathrm{CB}$ の存在しない系とほぼ同じ速度 で, 重合が進行するととがわかる。しかしながら，CB 表面へのポリ MMAのグラフト率は約15\%であり,グ ラフト効率は $0.5 \%$ にすぎない。従って, てのような系 では, CB は重合禁止剤として作用し, 誘導期の後は, 非グラフトポリマーの生成が, きわめて優勢仁起るてと がわかった。

とてろで，BPOB を開始剤に用いた MMA の重合の 様子は, Fig. 5 亿示した CB-POE の場合とは, 著しく 異なっている。Fig.1亿示した CB-Azoを用いて重合 を行った結果についてあ同様であるが，CB 表面任導入 した重合開始基からポリマーが生長する系では, CB 存 在下での重合系とは違って, 重合はdead-end 型となる ことがわかる。てれは, CB 存在下での重合系は, 開始 剂がモノマーに溶解しているのに対して, CB 表面から の重合系では，重合開始基が $\mathrm{CB}$ 表面上に存在する之い う差異に基づくものと推察されるが, さらに詳細な検討 が必要である。

Fig. 7 には, CB-POEを用いて, $e$ 值が負のスチレ

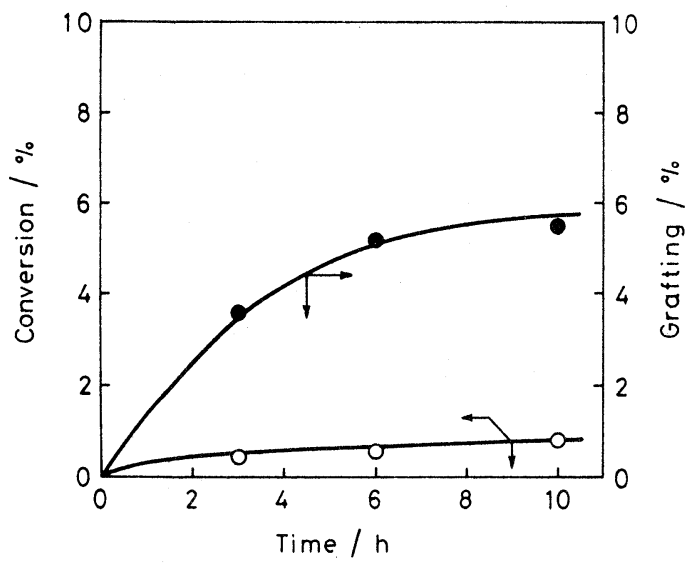

Fig. 7 Polymerization of styrene initiated by CB-POE. CB-POE, $0.30 \mathrm{~g}$; styrene, $10.0 \mathrm{ml} ; 70^{\circ} \mathrm{C}$.

ンの重合を行った結果を示した。 $e$ 值が正のMMA の系 (Fig. 5) とは異なり, この系では著しく重合が遅延され, 重合率は $1 \%$ に満たなかった。

また, Fig. 8 には, 未処理の $\mathrm{CB}$ 存在下でBPOB を 開始剂に用いて，スチレンの重合を行った結果を示した。 この系であ, CB が存在すると重合が著しく遅延され， CB-POEの系（Fig. 7）と同様の傾向を示すことが明 らかである。てのような結果は, Fig.4亿示した ACV を開始剤に用いた系とは対照的であった。

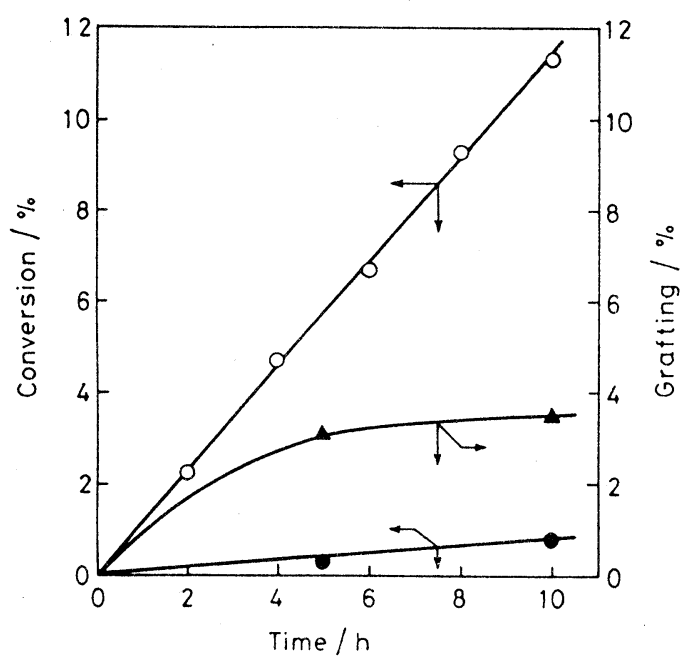

Fig. 8 Polymerization of styrene initiated by $\mathrm{BOPB}$ in the presence of untreated $\mathrm{CB}$. $\mathrm{CB}, 0.30 \mathrm{~g}$; $\mathrm{BPOB}, 0.012 \mathrm{mmol}$; styrene, $10.0 \mathrm{ml} ; 70^{\circ} \mathrm{C}$.

$O$ : in the absence of $\mathrm{CB}$.

$\bullet, \triangle$ : in the presence of $\mathrm{CB}$.

とてろで, $\mathrm{CB}$ の存在下で, 過酸化ベンゾイルを開始 剂记用いて $e$ 值が負のスチレンの重合を行うと, 著しい 重合遅延現象が観察されることが報告されている7)-9)。 そてで，CB-POEを用いたグラフト重合に及ぼす，モ ノマーの $e$ 値の効果をさらに明らかにするために, $e$ 值 の異なる種々のビニルモノマーの重合を行った。その結 果をTable 3 亿示した。

Table 3 Polymerization of various vinyl monomers initiated by CB-POE

\begin{tabular}{lrcr}
\hline Monomer & e-value & $\begin{array}{c}\text { Conversion } \\
(\%)\end{array}$ & $\begin{array}{c}\text { Grafting } \\
(\%)\end{array}$ \\
\hline$N$-Vinyl-2-pyrrolidone & -1.14 & 0.9 & 9.8 \\
Styrene & -0.80 & 0.5 & 5.2 \\
4-Vinylpyridine & -0.28 & 0.9 & 7.6 \\
Vinyl acetate & -0.22 & 0.2 & 2.3 \\
2-Hydroxyethyl methacrylate & 0.20 & 2.7 & 36.9 \\
Methyl methacrylate & 0.40 & 3.8 & 45.6 \\
Glycidyl methacrylate & 0.57 & 5.6 & 86.7 \\
Methyl vinyl ketone & 0.68 & 2.4 & 33.4 \\
Acrylic acid & 0.77 & 20.9 & 124.4 \\
Acrylonitrile & 1.20 & 10.8 & 77.5 \\
\hline
\end{tabular}

CB-POE, $0.30 \mathrm{~g}$; monomer, $10.0 \mathrm{ml} ; 70^{\circ} \mathrm{C}$.

CB-POE を用いると, $e$ 值が負の $N$-ビニル-2-ピロリ ドン，スチレン４-ビニルピリジン, 打よび酶酸ビニル などに対しては，重合が著しく遅延されることがわかる。 
これに対して, $e$ 值が正のモノマーに対しては, CB 表 函からグラフト重合が進行し, 高グラフト率のあのが得 られることが明らかである。從って, CB-POEを用いる と, $e$ 值が負のモノマーのグラフト重合は, 困難である ことが明らかになった。

な技, Table 1 からわかるように, CB 表面へのアゾ 基とパーオキシエステル基の導入量については, 大きな 差（パーオキシエステル基はアゾ基に対して約13\%）が 認められる。乙のととが, グラフト重合に何らかの影響 を及ぼしているとあ考えられるが，ててで得られた，モ ノマーの $e$ 值によってグラフト重合性が大きく異なると いう結果に対しては, 本質的な影響はないものと考えら れる。

\section{4. 総 括}

$\mathrm{CB}$ 表面からポリマーを生長させるラジカルグラフト 重合の系においても, モノマーの $e$ 值が, 重合性に大き な影響を及ぼすととが明らかになった。すなわち，アゾ 基を導入した $\mathrm{CB}$ では, $e$ 值が負のモノマーに対しては 重合が遅延される傾向にあるが, モノマーの $e$ 值にかか わらず, グラフト重合の進行が認められた。一方, パー オキシェステル基を導入した CBでは, $e$ 值が正のモノ マーに対してはグラフト重合が進行するが, 負のモノマ 一に対しては, 著しい重合遅延現象が認められ, CB 表 面へのポリマーのグラフトは, ほとんど起てらないこと がわかった。

てのような知見は, グラフト化による CB 表面の機能 設計を行うにあたり, 有効に利用できる屯のと考えられ る。

\section{文献}

1) 坪川紀夫, 畺根康夫: 高分子加工 33, 129 (1984)

2) 坪川紀夫, 日本ゴム協会誌 58, 306 (1985)

3) N. Tsubokawa, A. Yamada and Y. Sone, Polym. Bull. 10, 63 (1983)
4) N. Tsubokawa, H. Nunokawa and Y. Sone, J. Macromol. Sci.-Chem. A23, 105 (1986)

5) N. Tsubokawa, Y. Nagano and Y. Sone, Polym. Bull. 7, 589 (1982)

6) 大北熊一, 中山直樹, 大滝 徹, 色材協会誌 54 , 263 (1981)

7) K. Ohkita, N. Tsubokawa, E. Saitoh, M. Noda and N. Takashina, Carbon 13, 443 (1975)

8) 大北熊一, 坪川紀夫, 高科直光, 日本ゴム協会誌 49, 223 (1976)

9) K. Ohkita, N. Tsubokawa and E. Saitoh, Carbon 16, 41 (1978)

10) 坪川紀夫, 藤木一浩, 兽根康夫, 高分子学会予稿集 35,300 (1986)

11) N. Tsubokawa, K. Fujiki and Y. Sone, Polym. J. 20, 213 (1988)

12) T. Alfrey Jr. and C.C. Price, J. Polym. Sci. 2, 101 (1947)

13) 大津隆行, “改訂高分子合成の化学”, 化学同人 (1979) p. 116

14) カーボンブラック協会編, “カーボンブラック便 覧”, 図書出版社 (1971) p. 426

15) R. Yosomiya, T. Fujisawa and K. Morimoto, Polym. Bull. 12, 523 (1984)

16) R. Yosomiya, K. Morimoto and T. Suzuki, J. Appl. Polym. Sci. 29, 671 (1984)

17) 三枝武夫, 野崎正士, 小田良平, 工業化学雑誌 57, 243 (1954); 57, 333 (1954)

18) J.W. Breitenbach and H. Preussler, J. Polym. Sci. 4, 751 (1949)

19) G. Kraus, J.T. Gruver and K.W. Rollmann, J. Polym. Sci. 36, 564 (1959)

20) J.B. Donnet and G. Henrich, J. Polym. Sci. 46, 277 (1960)

21) 大北熊一, 坪川紀夫, 斉藤英一, 野田雅之, 江口宏 喜, 日本ゴム協会誌 49, 900 (1976) 